\title{
Observations on haemodynamic effects of mexiletine
}

\author{
N. P. S. CAMPBELl, S. A. ZAIDi, A. A. J. ADGEY, G. C. PATTERSON, \\ AND J. F. PANTRIDGE \\ From the Department of Cardiology, Royal Victoria Hospital, Belfast
}

SUMMARY The haemodynamic effects of intravenous mexiletine have been studied in 16 patients with valvular heart disease without clinical evidence of heart failure.

A bolus injection of $150 \mathrm{mg}$ administered to 6 of the 16 patients resulted in a mean plasma concentration above the therapeutic range for at least 5 minutes after the drug was given. A small but significant rise in the mean pulmonary artery pressure occurred.

In 10 patients, the effects of intravenous mexiletine were compared with those of intravenous saline in a double blind trial. No significant difference was found in the haemodynamic effects, though both saline and mexiletine produced a small rise in the mean pulmonary artery pressure.

Mexiletine when administered to patients without heart failure in doses known to be clinically effective did not have important adverse haemodynamic effects.

Mexiletine, a relatively new antiarrhythmic drug, when given intravenously controls ventricular arrhythmias (Campbell et al., 1977). Adverse haemodynamic effects were not observed when doses of from 50 to $140 \mathrm{mg}$ were injected intravenously (Banim et al., 1977; Pozenel, 1977). These doses are smaller than those used in clinical practice (Campbell et al., 1977; Prescott, 1977). Preliminary studies from our laboratory showed a statistically significant fall in cardiac index and a rise in systemic vascular resistance in patients receiving $100 \mathrm{mg}$ mexiletine intravenously (Campbell, 1976).

The investigation reported here was designed to clarify the haemodynamic effects of mexiletine given in bolus injections which are clinically effective.

Received for publication 14 June 1978

\section{Patients and methods}

The studies were performed in 16 patients undergoing cardiac catheterisation. Five patients had mitral valve disease, 2 had aortic valve disease, and 9 had disease of both valves. Two patients had grade 1 and 14 grade 2 disability (New York Heart Association classification) (Table 1). None had clinical evidence of heart failure. Thirteen were on maintenance digoxin therapy.

The procedure was explained and the patients' consent obtained. All were studied fasting and had received $50 \mathrm{mg}$ pethidine and $5 \mathrm{mg}$ droperidol by intramuscular injection at least $1 \frac{1}{2}$ hours before the investigation. The local anaesthetic was lignocaine, injected subcutaneously in a dose of 200 to $400 \mathrm{mg}$. The mean plasma concentration of lignocaine was $1.4 \mu \mathrm{g} / \mathrm{ml}$ (range 0.44 to $2.9 \mu \mathrm{g} / \mathrm{ml}$ ).

Table 1 Details of patients

\begin{tabular}{|c|c|c|c|c|c|c|c|c|c|c|c|}
\hline & & \multirow[t]{2}{*}{ Patients } & \multirow{2}{*}{$\begin{array}{l}\text { Age } \\
(y) \\
\text { (mean } \\
\pm S E M\end{array}$} & \multicolumn{2}{|c|}{ Sex } & \multirow{2}{*}{$\begin{array}{l}\text { Weight } \\
(\text { kg) } \\
(\text { mean } \\
\pm S E M)\end{array}$} & \multicolumn{2}{|c|}{ Functional class } & \multicolumn{2}{|c|}{ Rhythm } & \multirow{2}{*}{$\begin{array}{l}\text { No. } \\
\text { receiving } \\
\text { digoxin }\end{array}$} \\
\hline & & & & $M$ & $\boldsymbol{F}$ & & & $I I$ & $S R$ & $\boldsymbol{A F}$ & \\
\hline & $150 \mathrm{mg}$ Mexiletine & 6 & $\begin{array}{r}45 \cdot 0 \\
\pm 5 \cdot 1\end{array}$ & 3 & 3 & $\begin{array}{r}67 \cdot 0 \\
\pm 5 \cdot 8\end{array}$ & 2 & 4 & 3 & 3 & 3 \\
\hline \multirow{2}{*}{$\begin{array}{l}\text { Double blind } \\
\text { comparison }\end{array}$} & $\int 2.75 \mathrm{mg} / \mathrm{kg}$ Mexiletine & 5 & $\begin{array}{r}44 \cdot 0 \\
\pm 2 \cdot 8\end{array}$ & 3 & 2 & $\begin{array}{r}69 \cdot 0 \\
\pm 7 \cdot 7\end{array}$ & 0 & 5 & 2 & 3 & 5 \\
\hline & Saline & 5 & $\begin{array}{r}44 \cdot 0 \\
\pm 5 \cdot 4\end{array}$ & 3 & 2 & $\begin{array}{r}61 \cdot 0 \\
\pm 4 \cdot 6\end{array}$ & 0 & 5 & 1 & 4 & 5 \\
\hline
\end{tabular}

SEM, standard error of mean; SR, sinus rhythm; AF, atrial fibrillation; *New York Heart Association classification. 
The study was carried out in 2 parts. Six patients received $150 \mathrm{mg}$ by intravenous injection and 10 were studied in a randomised double blind controlled comparison of the effects of mexiletine and saline (Table 1). In the 6 patients who were to receive $150 \mathrm{mg}$, right heart catheterisation was performed, using a double-lumen Cournand catheter inserted into a median cubital vein. The right atrial pressure was measured. The catheter was then advanced to the pulmonary wedge position. Simultaneous recordings of the pulmonary artery and pulmonary wedge pressures were obtained.

In the 10 patients in the double blind trial, the right heart was catheterised by a double-lumen flow directed balloon catheter. Positioning of the catheter allowed recording of the pulmonary arterial or pulmonary arterial occluded pressure simultaneously with the right atrial pressure. The pulmonary arterial occluded pressure "was assumed to be identical to the pulmonary wedge pressure.

In all 16 patients, a number 7 Gensini catheter was introduced into a femoral artery and passed retrogradely into the left ventricular cavity. $A 15 \mathrm{~cm}$ 'teflon' catheter was inserted into the other femoral artery. The electrocardiogram and all pressures were recorded on a direct writing 8-channel Mingograf 81 recorder. This machine was equipped with an ink jet recorder and had a linear frequency response from 0 to $500 \mathrm{~Hz}$. The sternal angle was taken as the zero reference for all pressure measurements.

Tracings were obtained of the electrocardiogram and the left ventricular, pulmonary arterial, pulmonary wedge, or pulmonary arterial occluded and femoral arterial pressures at a paper speed of $25 \mathrm{~mm} / \mathrm{second}$. When the balloon catheter was used, the right atrial and pulmonary arterial pressures were measured simultaneously. In all studies immediately following the pressure recordings, the cardiac output was determined by the dye dilution method, using indocyanine green. The dye was injected into the pulmonary artery or right atrium and blood withdrawn through the femoral arterial catheter using a constant rate withdrawal pump. Changes in dye concentration were detected by a Gilford densitometer and displayed on a Texas instruments recorder.

The left ventricular end-diastolic pressure (LVEDP) was taken as the pressure immediately before the rapid rise caused by ventricular contraction. The mean right atrial and pulmonary wedge pressures were estimated from their tracings. Pressure determinations were made by analysis of 6 or more beats.

The systemic and pulmonary vascular resistances (SVR and PVR) were calculated: SVR = (mean femoral arterial pressure - mean right atrial pressure) $\div \mathrm{CO} ; \mathrm{PVR}=$ (mean pulmonary arterial pressure - mean pulmonary wedge pressure) CO. Stroke work index (SWI) was derived from the formula SWI $=($ LVMSP - LVEDP $) \times$ Cardiac index Heart rate $\times 0.0136 \mathrm{~g} \mathrm{~m} /$ beat per $\mathrm{m}^{2}$ (Grossman, 1974) (LVMSP = the left ventricular mean systolic pressure $=0.9 \times$ peak left ventricular systolic pressure (Russell et al., 1970)).

In all studies, control measurements were made approximately 5 and 2 minutes before the administration of the drug. The $150 \mathrm{mg}$ injection of mexiletine was given at a rate of $40 \mathrm{mg} /$ minute. Recordings were repeated $2,5,10,15$, and 20 minutes after the completion of the injection. Blood samples were withdrawn after 2,5 , and 20 minutes for determination of the plasma concentration of mexiletine (Kelly, 1977).

In the randomised double blind controlled study, 5 patients received mexiletine in a dose of $2.75 \mathrm{mg} / \mathrm{kg}$ body weight. Five patients received an intravenous injection of similar volumes of normal saline. The drug or saline was infused over 2.5 minutes. Patients in the 2 groups were matched for age, sex, and heart size determined from the chest $x$-ray film. Pressure recordings and determination of cardiac output were made 2,5 , and 10 minutes after the completion of the injections. The results were calculated without knowledge of whether drug or saline had been given.

Statistical comparisons within groups of patients were made using Student's t test for paired differences. The statistical differences between mean values were determined with Student's unpaired t test.

\section{Results}

Table 2 shows the results after the administration of $150 \mathrm{mg}$ mexiletine to 6 patients. Apart from a small rise in the mean pulmonary artery pressure, statistically significant changes did not occur.

Two minutes after completion of the injection, the mean plasma concentration of mexiletine was $3.9 \pm 1.7(\mathrm{SEM}) \mu \mathrm{g} / \mathrm{ml}$. Three minutes later, the mean value had fallen to $2.3 \pm 1.2(\mathrm{SEM}) \mu \mathrm{g} / \mathrm{ml}$. Twenty minutes after the injection, the mean concentration had fallen to $0.4 \pm 0.1$ (SEM) $\mu \mathrm{g} / \mathrm{ml}$.

The results of the randomised trial are shown in Table 3. Five patients received mexiletine in a dose of $2.75 \mathrm{mg} / \mathrm{kg}$ and, in these patients, the only statistically significant change was an increase in the mean pulmonary artery pressure. It rose from a mean value of $16 \mathrm{mmHg}$ to $19 \mathrm{mmHg} 2$ minutes after the injection was given. 
Table 2 Haemodynamic effects of intravenous injection of $150 \mathrm{mg}$ mexiletine in 6 patients

\begin{tabular}{|c|c|c|c|c|c|c|c|}
\hline & & \multirow[t]{2}{*}{ Control } & \multicolumn{5}{|c|}{ Minutes after injection } \\
\hline & & & 2 & 5 & 10 & 15 & 20 \\
\hline Heart rate (beats/min) & $\begin{array}{l}\text { Mean } \\
\pm \text { SEM }\end{array}$ & $\begin{array}{l}69 \\
3 \cdot 7\end{array}$ & $\begin{array}{l}71 \\
5.9\end{array}$ & 71 & $\begin{array}{r}70 \cdot 5 \\
6.0\end{array}$ & $\begin{array}{l}70 \\
5 \cdot 5\end{array}$ & $\begin{array}{l}69 \\
4 \cdot 9\end{array}$ \\
\hline $\begin{array}{l}\text { Mean pulmonary artery pressure } \\
\text { (mmHg) }\end{array}$ & $\begin{array}{l}\text { Mean } \\
\pm \text { SEM }\end{array}$ & $\begin{array}{l}13 \\
1.9\end{array}$ & $\begin{array}{l}13 \\
1.9\end{array}$ & $\begin{array}{c}15^{\star} \\
2 \cdot 4\end{array}$ & $\begin{array}{l}15 \\
2 \cdot 6\end{array}$ & $\begin{array}{c}14 \dagger \\
1.8\end{array}$ & 13 \\
\hline $\begin{array}{l}\text { Mean femoral artery pressure } \\
(\mathbf{m m H g})\end{array}$ & $\begin{array}{l}\text { Mean } \\
\pm \text { SEM }\end{array}$ & $\begin{array}{l}74 \\
3.8\end{array}$ & $\begin{array}{l}72 \\
3.5\end{array}$ & $\begin{array}{l}75 \\
5 \cdot 1\end{array}$ & $\begin{array}{l}74 \\
4 \cdot 0\end{array}$ & $\begin{array}{l}75 \\
3.9\end{array}$ & $\begin{array}{l}75 \\
4 \cdot 2\end{array}$ \\
\hline $\begin{array}{l}\text { Left ventricular end-diastolic pressure } \\
(\mathrm{mmHg})\end{array}$ & $\begin{array}{l}\text { Mean } \\
\pm \text { SEM }\end{array}$ & $\begin{array}{l}6 \\
0 \cdot 7\end{array}$ & $\begin{array}{l}6 \cdot 5 \\
0 \cdot 8\end{array}$ & $\begin{array}{l}7 \\
1 \cdot 4\end{array}$ & $\begin{array}{l}5 \\
0.7\end{array}$ & $\begin{array}{l}4 \\
0 \cdot 3\end{array}$ & $\begin{array}{l}6 \\
0.9\end{array}$ \\
\hline $\begin{array}{l}\text { Cardiac index } \\
\left(1 / \text { min per } \mathrm{m}^{2}\right)\end{array}$ & $\begin{array}{l}\text { Mean } \\
\pm \text { SEM }\end{array}$ & $\begin{array}{l}2 \cdot 3 \\
0 \cdot 20\end{array}$ & $\begin{array}{l}2 \cdot 1 \\
0 \cdot 37\end{array}$ & $\begin{array}{l}2 \cdot 3 \\
0 \cdot 37\end{array}$ & $\begin{array}{l}2 \cdot 2 \\
0 \cdot 39\end{array}$ & $\begin{array}{l}2 \cdot 4 \\
0 \cdot 41\end{array}$ & $\begin{array}{l}2 \cdot 3 \\
0 \cdot 41\end{array}$ \\
\hline $\begin{array}{l}\text { Stroke work index } \\
\left(\mathrm{g} \mathrm{m} / \text { beat per } \mathrm{m}^{2}\right)\end{array}$ & $\begin{array}{l}\text { Mean } \\
\pm \text { SEM }\end{array}$ & $\begin{array}{l}45 \\
5 \cdot 7\end{array}$ & $\begin{array}{l}40 \\
7 \cdot 7\end{array}$ & $\begin{array}{l}44 \\
8 \cdot 1\end{array}$ & $\begin{array}{l}43 \\
8 \cdot 4\end{array}$ & $\begin{array}{l}51 \\
12 \cdot 3\end{array}$ & $\begin{array}{l}47 \\
9 \cdot 1\end{array}$ \\
\hline $\begin{array}{l}\text { Pulmonary vascular resistance } \\
\text { (dynes } \mathrm{cm}^{-5} \text { ) }\end{array}$ & $\begin{array}{l}\text { Mean } \\
\pm \text { SEM }\end{array}$ & $\begin{array}{r}140 \\
22\end{array}$ & $\begin{array}{r}140 \\
27\end{array}$ & $\begin{array}{r}190 \\
48\end{array}$ & $\begin{array}{r}230 \\
82\end{array}$ & $\begin{array}{r}160 \\
38\end{array}$ & $\begin{array}{r}160 \\
31\end{array}$ \\
\hline $\begin{array}{l}\text { Systemic vascular resistance } \\
\text { (dynes } 8 \mathrm{~cm}^{-5} \text { ) }\end{array}$ & $\begin{array}{l}\text { Mean } \\
\pm \text { SEM }\end{array}$ & $\begin{array}{r}1570 \\
160\end{array}$ & $\begin{array}{r}1850 \\
333\end{array}$ & $\begin{array}{r}1710 \\
294\end{array}$ & $\begin{array}{c}1810 \\
333\end{array}$ & $\begin{array}{c}1720 \\
347\end{array}$ & $\begin{array}{c}1770 \\
287\end{array}$ \\
\hline
\end{tabular}

Saline was given to 5 patients (Table 3). Five minutes after the injection, a mean increase in the mean pulmonary arterial pressure was observed. Five and 10 minutes after the saline injection, the

mean femoral artery pressure increased by $4 \mathrm{mmHg}$. These changes were statistically significant. When the results obtained after 2,5 , and 10 minutes were combined, there were significant increases in the

Table 3 Haemodynamic effects of mexiletine and saline

\begin{tabular}{|c|c|c|c|c|c|c|c|c|c|c|c|}
\hline & & \multicolumn{5}{|c|}{ Mexiletine (5 patients) } & \multicolumn{5}{|c|}{ Saline ( 5 patients) } \\
\hline & & \multirow[t]{2}{*}{ Control } & \multicolumn{3}{|c|}{ Minutes after injection } & \multirow[t]{2}{*}{ Total } & \multirow[t]{2}{*}{ Control } & \multicolumn{3}{|c|}{ Minutes after injection } & \multirow[t]{2}{*}{ Total } \\
\hline & & & 2 & 5 & 10 & & & 2 & 5 & 10 & \\
\hline $\begin{array}{l}\text { Heart rate } \\
\text { (beats } / \mathrm{min})\end{array}$ & $\begin{array}{l}\text { Mean } \\
\pm \text { SEM }\end{array}$ & $\begin{array}{l}62 \\
4 \cdot 8\end{array}$ & $\begin{array}{l}66 \\
4 \cdot 3\end{array}$ & $\begin{array}{l}64 \\
4 \cdot 3\end{array}$ & $\begin{array}{l}64 \\
3 \cdot 3\end{array}$ & $\begin{array}{l}64 \\
3 \cdot 8\end{array}$ & $\begin{array}{l}68 \\
9 \cdot 1\end{array}$ & $\begin{array}{l}69 \\
8 \cdot 9\end{array}$ & $\begin{array}{l}69 \\
8 \cdot 8\end{array}$ & $\begin{array}{l}70 \\
9 \cdot 6\end{array}$ & $\begin{array}{l}69 \\
9 \cdot 1\end{array}$ \\
\hline $\begin{array}{l}\text { Mean pulmonary artery pressure } \\
(\mathrm{mmHg})\end{array}$ & $\begin{array}{l}\text { Mean } \\
\pm \text { SEM }\end{array}$ & $\begin{array}{c}16 \\
2 \cdot 7\end{array}$ & $\begin{array}{r}19 \star \\
3 \cdot 0\end{array}$ & $\begin{array}{c}18 \\
2 \cdot 9\end{array}$ & $\begin{array}{c}19 \\
3 \cdot 4\end{array}$ & $\begin{array}{c}19 \\
3 \cdot 0\end{array}$ & $\begin{array}{c}19 \\
3.0\end{array}$ & $\begin{array}{l}20 \\
3 \cdot 3\end{array}$ & $\begin{array}{r}21 * \\
3 \cdot 3\end{array}$ & $\begin{array}{c}19 \\
2 \cdot 7\end{array}$ & $\begin{array}{l}20 \\
3 \cdot 1\end{array}$ \\
\hline $\begin{array}{l}\text { Mean femoral artery pressure } \\
(\mathrm{mmHg})\end{array}$ & $\begin{array}{l}\text { Mean } \\
\pm \text { SEM }\end{array}$ & $\begin{array}{l}77 \\
5 \cdot 7\end{array}$ & $\begin{array}{l}79 \\
6 \cdot 2\end{array}$ & $\begin{array}{l}72 \\
2 \cdot 5\end{array}$ & $\begin{array}{l}77 \\
3 \cdot 5\end{array}$ & $\begin{array}{l}76 \\
2 \cdot 9\end{array}$ & $\begin{array}{l}68 \\
7 \cdot 8\end{array}$ & $\begin{array}{c}69 \\
7 \cdot 7\end{array}$ & $\begin{array}{r}72 \star \\
8 \cdot 5\end{array}$ & $\begin{array}{c}72 \dagger \\
7 \cdot 9\end{array}$ & $\begin{array}{c}71^{\star} \\
8 \cdot 0\end{array}$ \\
\hline $\begin{array}{l}\text { Left ventricular peak systolic } \\
\text { pressure (mmHg) }\end{array}$ & $\begin{array}{l}\text { Mean } \\
\pm \text { SEM }\end{array}$ & $\begin{array}{c}109 \\
10 \cdot 8\end{array}$ & $\begin{array}{l}106 \\
7 \cdot 5\end{array}$ & $\begin{array}{l}105 \\
7 \cdot 6\end{array}$ & $\begin{array}{r}101 \\
5 \cdot 0\end{array}$ & $\begin{array}{r}104 \\
6 \cdot 0\end{array}$ & $\begin{array}{l}98 \\
9 \cdot 7\end{array}$ & $\begin{array}{l}102 \\
9 \cdot 5\end{array}$ & 100 & $\begin{array}{r}99 \\
7 \cdot 9\end{array}$ & $\begin{array}{r}100 t \\
9 \cdot 6\end{array}$ \\
\hline $\begin{array}{l}\text { Left ventricular end-diastolic } \\
\text { pressure }\left(\mathrm{mmHg}^{\mathrm{m}}\right)\end{array}$ & $\begin{array}{l}\text { Mean } \\
\pm \text { SEM }\end{array}$ & $\begin{array}{l}6 \\
2 \cdot 0\end{array}$ & $\begin{array}{l}8 \\
2 \cdot 4\end{array}$ & $\begin{array}{l}8 \\
2 \cdot 2\end{array}$ & $\begin{array}{l}5 \\
2 \cdot 0\end{array}$ & $\begin{array}{l}7 \\
2 \cdot 2\end{array}$ & $\begin{array}{l}6 \\
1 \cdot 7\end{array}$ & $\begin{array}{l}6 \\
2 \cdot 1\end{array}$ & $\begin{array}{l}6 \\
2 \cdot 1\end{array}$ & $\begin{array}{l}5 \\
2 \cdot 7\end{array}$ & $\begin{array}{l}6 \\
2 \cdot 25\end{array}$ \\
\hline $\begin{array}{l}\text { Cardiac index } \\
\left(1 / \mathrm{min} \text { per } \mathrm{m}^{2}\right)\end{array}$ & $\begin{array}{l}\text { Mean } \\
\pm \text { SEM }\end{array}$ & $\begin{array}{l}2 \cdot 3 \\
0.35\end{array}$ & $\begin{array}{l}2.4 \\
0.92\end{array}$ & $\begin{array}{l}(2 \cdot 2) \\
(0 \cdot 37)\end{array}$ & $\begin{array}{l}2 \cdot 5 \\
0 \cdot 25\end{array}$ & $\begin{array}{l}2 \cdot 4 \\
0 \cdot 30\end{array}$ & $\begin{array}{l}2 \cdot 0 \\
0 \cdot 18\end{array}$ & $\begin{array}{l}2 \cdot 0 \\
0 \cdot 22\end{array}$ & $\begin{array}{l}2 \cdot 1 \\
0 \cdot 21\end{array}$ & $\begin{array}{l}2 \cdot 1 \\
0 \cdot 26\end{array}$ & $\begin{array}{l}2 \cdot 1 \\
0 \cdot 22\end{array}$ \\
\hline $\begin{array}{l}\text { Stroke work index } \\
\left(\mathrm{g} \mathrm{m} / \text { beat per } \mathrm{m}^{2}\right)\end{array}$ & $\begin{array}{l}\text { Mean } \\
\pm \text { SEM }\end{array}$ & $\stackrel{45}{5 \cdot 5}$ & $\frac{43}{6 \cdot 5}$ & $\begin{array}{l}(44) \\
(6 \cdot 0)\end{array}$ & $\stackrel{46}{5 \cdot 0}$ & $\stackrel{44}{5 \cdot 0}$ & $\begin{array}{l}35 \\
5 \cdot 4\end{array}$ & $\begin{array}{l}36 \\
6.5\end{array}$ & $\begin{array}{l}36 \\
5 \cdot 5\end{array}$ & $\begin{array}{r}37 \\
6.9\end{array}$ & $\begin{array}{l}36 \\
6 \cdot 2\end{array}$ \\
\hline $\begin{array}{l}\text { Pulmonary vascular resistance } \\
\text { (dynes } 8 \mathrm{~cm}^{-5} \text { ) }\end{array}$ & $\begin{array}{l}\text { Mean } \\
\pm \text { SEM }\end{array}$ & $\begin{array}{r}190 \\
57\end{array}$ & $\begin{array}{r}200 \\
51\end{array}$ & $\begin{array}{r}(170) \\
(57)\end{array}$ & $\begin{array}{r}180 \\
43\end{array}$ & $\begin{array}{r}190 \\
48\end{array}$ & $\begin{array}{r}210 \\
40\end{array}$ & $\begin{array}{r}180 \\
40\end{array}$ & $\begin{array}{r}180 \\
46\end{array}$ & $\begin{array}{r}180 \\
28\end{array}$ & $\begin{array}{r}170 \\
34\end{array}$ \\
\hline $\begin{array}{l}\text { Systemic vascular resistance } \\
\text { (dynes } \mathrm{cm}^{-5} \text { ) }\end{array}$ & $\begin{array}{l}\text { Mean } \\
\pm \text { SEM }\end{array}$ & $\begin{array}{r}1660 \\
264\end{array}$ & $\begin{array}{r}1570 \\
235\end{array}$ & $\begin{array}{r}(1470) \\
(218)\end{array}$ & $\begin{array}{r}1400 \\
157\end{array}$ & $\begin{array}{r}1490 \\
174\end{array}$ & $\begin{array}{r}1630 \\
267\end{array}$ & $\begin{array}{r}1640 \\
220\end{array}$ & $\begin{array}{r}1650 \\
285\end{array}$ & $\begin{array}{r}1680 \\
269\end{array}$ & $\begin{array}{r}1660 \\
250\end{array}$ \\
\hline \multicolumn{12}{|c|}{ 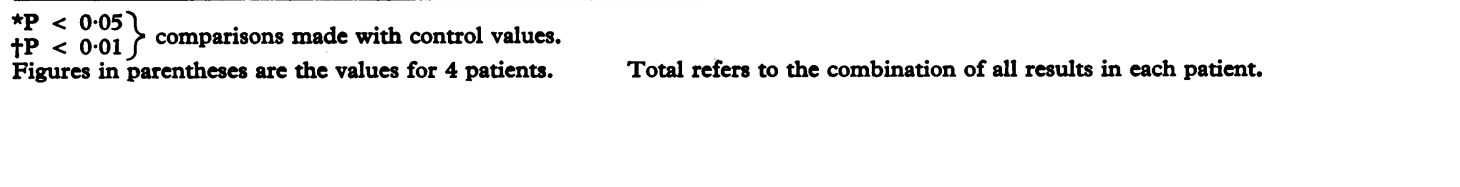 } \\
\hline
\end{tabular}


mean femoral artery and in the left ventricular peak systolic pressures.

When the results in the mexiletine group were compared with those in the patients who received saline, the mean changes in the measured and derived variables showed no statistically significant differences.

\section{Discussion}

The work of Singh and Vaughan Williams (1972) showed that mexiletine reduced the maximum amplitude of contraction of isolated rabbit atria. The effect occurred when the drug was present in the protein-free perfusate in a concentration of $3 \mu \mathrm{g} / \mathrm{ml}$. Shaw (1977) used ball valve travel time in patients with a Starr-Edwards aortic prosthesis as an index of myocardial contractility. Travel time was significantly prolonged after $50 \mathrm{mg}$ and $100 \mathrm{mg}$ injections of mexiletine intravenously. The changes produced were similar to those observed with comparable doses of lignocaine. Saunamäki (1975) observed impairment of myocardial function in 3 of 6 patients with ischaemic heart disease who were given the drug by intravenous infusion. He gave $10 \mathrm{mg} /$ minute for 10 minutes followed by a $6.5 \mathrm{mg} /$ minute infusion for up to 12 minutes. The mean plasma concentration of mexiletine was $>1 \mu \mathrm{g} / \mathrm{ml}$ during the period of study. This is within the therapeutic range (Campbell et al., 1978). The resting pulmonary wedge pressures of the 3 patients whose myocardial function deteriorated were $13 \mathrm{mmHg}$ or higher and all had a current or past history of heart failure. We have previously reported the effects of mexiletine when systolic time intervals were used as an index of myocardial function (Campbell et al., 1977). The ratio of the pre-ejection period to the left ventricular ejection time increased after the injection of $200 \mathrm{mg}$ mexiletine in 6 patients with ischaemic heart disease. The change was most pronounced in 1 patient who had had congestive heart failure.

Banim et al. (1977) investigated the effects of mexiletine in patients with ischaemic heart disease whose mean left ventricular filling pressure at rest was $15.2 \mathrm{mmHg}$. No significant haemodynamic changes were observed when doses of $1.5 \mathrm{mg} / \mathrm{kg}$ (105 to $140 \mathrm{mg}$ ) were injected intravenously. Pozenel (1977) gave single injections of 50 or $100 \mathrm{mg}$ and followed these by intravenous infusions of up to $500 \mathrm{mg}$ within 50 minutes. No haemodynamic changes occurred.

The results of the present study are in keeping with the findings of Banim et al. (1977) and Pozenel (1977). We used larger doses and found that the only statistically significant change was a small rise in the mean pulmonary arterial pressure. A similar small rise was also observed in the patients who received saline. The doses of mexiletine which we used- $150 \mathrm{mg}$ and $2.75 \mathrm{mg} / \mathrm{kg}$ - are known to be effective in the control of ventricular arrhythmias (Campbell et al., 1977; Prescott, 1977). The injection of $150 \mathrm{mg}$ produced mean plasma concentrations of mexiletine above $2 \mu \mathrm{g} / \mathrm{ml}$ for at least 5 minutes. This level has been proposed as the upper limit of the therapeutic range of the drug (Campbell et al., 1978). It is of interest that though lignocaine given for local anaesthesia resulted in a mean plasma concentration of $1.4 \mu \mathrm{g} / \mathrm{ml}$ no adverse interaction with mexiletine was observed.

Why some workers have shown negative inotropic effects whereas others have not may be explained by differences in the doses given or by the clinical status of the patients. A negative inotropic effect might be expected to occur more readily in those with poor left ventricular function. The intravenous injection of $200 \mathrm{mg}$ mexiletine (Campbell et al., 1977) or the administration of doses sufficient to raise the plasma concentration to adequate levels (Saunamäki, 1975) impaired cardiac performance, particularly when there was evidence of cardiac decompensation. Doses of $100 \mathrm{mg}$ or less caused no deterioration in haemodynamics when the mean left ventricular filling pressure was normal (Pozenel, 1977). In the present study, none of the patients had clinical evidence of heart failure and only 1 had a left ventricular end-diastolic pressure above $13 \mathrm{mmHg}$. Doses of $150 \mathrm{mg}$ or $2.75 \mathrm{mg} / \mathrm{kg}$ did not affect cardiac performance.

It is concluded that the intravenous administration of mexiletine in clinically effective dosage produced no adverse haemodynamic effects in patients without clinical evidence of heart failure.

We thank Dr John Kelly for the determination of the plasma concentrations of mexiletine and lignocaine.

\section{References}

Banim, S. O., Da Silva, A., Stone, D., and Balcon, R. (1977). Observations of the haemodynamics of mexiletine. Postgraduate Medical fournal, 53, Suppl. 1, 74-77.

Campbell, N. P. S. (1976). Studies with antiarrhythmic drugs, p. 128. M.D. Thesis, Belfast.

Campbell, N. P. S., Kelly, J. G., Adgey, A. A. J., and Shanks, R. G. (1978). The clinical pharmacology of mexiletine. British fournal of Clinical Pharmacology, 6, 103-108.

Campbell, N. P. S., Kelly, J. G., Chaturvedi, N. C., Strong, J. E., Shanks, R. G., and Adgey, A. A. J. (1977). The development of mexiletine in the management of ventricular dysrhythmias. Postgraduate Medical fournal, 53, Suppl. 1, 114-119.

Grossman, W. (1974). Normal Values in Cardiac Catheterisation and Angiography, p. 329. Ed. by W. Grossman. Lea and Febiger, Philadelphia. 
Kelly, J. G. (1977). Measurement of plasma mexiletine concentrations. Postgraduate Medical fournal, 53, Suppl. 1, 48-49.

Pozenel, H. (1977). Haemodynamic studies on mexiletine, a new antiarrhythmic agent. Postgraduate Medical fournal, 53, Suppl. 1, 78-80.

Prescott, L. F. (1977). The development of intravenous mexiletine dose regimes. Postgraduate Medical fournal, 53, Suppl. 1, 124-127.

Russell, R. O., Jr., Rackley, C. E., Pombo, J., Hunt, D., Potanin, C., and Dodge, H. T. (1970). Effects of increasing left ventricular filling pressure in patients with acute myocardial infarction. Fournal of Clinical Investigation, 49, 1539-1550.

Saunamäki, K. I. (1975). Haemodynamic effects of a new antiarrhythmic agent, mexiletine (Ko 1173) in ischaemic heart disease. Cardiovascular Research, 9, 788-792.

Shaw, T. R. D. (1977). The effect of mexiletine on left ventricular ejection: a comparison with lignocaine and propranolol. Postgraduate Medical fournal, 53, Suppl. 1, 69-73.

Singh, B. N., and Vaughan Williams, E. M. (1972). Investigations of the mode of action of a new antidysrhythmic drug, Ko 1173. British Fournal of Pharmacology, 44, 1-9.

Requests for reprints to Dr A. A. J. Adgey, Department of Cardiology, Royal Victoria Hospital, Grosvenor Road, Belfast BT12 6BA, Northern Ireland. 